\title{
Towards solar cells with black silicon texturing passivated by a-Si:H
}

landolo, Beniamino; Plakhotnyuk, Maksym; Davidsen, Rasmus S.; Stamate, Eugen; Hansen, Ole; Nunomura, Shota

\section{Published in:}

Proceedings of the 7th IEEE World Conference on Photovoltaic Energy Conversion (WCPEC 2018)

Link to article, DOI:

10.1109/PVSC.2018.8547828

Publication date:

2018

Document Version

Peer reviewed version

Link back to DTU Orbit

\section{Citation (APA):}

landolo, B., Plakhotnyuk, M., Davidsen, R. S., Stamate, E., Hansen, O., \& Nunomura, S. (2018). Towards solar cells with black silicon texturing passivated by a-Si: $\mathrm{H}$. In Proceedings of the 7th IEEE World Conference on Photovoltaic Energy Conversion (WCPEC 2018): (A Joint Conference of 45th IEEE PVSC, 28th PVSEC \& 34th EU PVSEC) (pp. 2135-2137). IEEE. Conference Record of the IEEE Photovoltaic Specialists Conference https://doi.org/10.1109/PVSC.2018.8547828

\section{General rights}

Copyright and moral rights for the publications made accessible in the public portal are retained by the authors and/or other copyright owners and it is a condition of accessing publications that users recognise and abide by the legal requirements associated with these rights.

- Users may download and print one copy of any publication from the public portal for the purpose of private study or research.

- You may not further distribute the material or use it for any profit-making activity or commercial gain

- You may freely distribute the URL identifying the publication in the public portal 


\title{
Towards solar cells with black silicon texturing passivated by a-Si:H
}

\author{
Beniamino Iandolo ${ }^{1}$, Maksym Plakhotnyuk ${ }^{2}$, Rasmus. S. Davidsen ${ }^{1}$, Eugen Stamate ${ }^{2}$, Ole Hansen ${ }^{1}$ and \\ Shota Nunomura ${ }^{3}$ \\ ${ }^{1}$ Technical University of Denmark, Department of Micro-and Nanotechnology, Ørsteds plads 345, Kgs. \\ Lyngby, DK-2800, Denmark \\ ${ }^{2}$ Technical University of Denmark, Department of Energy Conversion and Storage, Frederiksborgvej 399, \\ Roskilde, 4000, Denmark \\ ${ }^{3}$ Research Center for Photovoltaics, National Institute of Advanced Industrial Science and Technology \\ (AIST), 1-1-1 Umezono, Tsukuba, Ibaraki 305-8568, Japan
}

\begin{abstract}
We introduce surfaces of black silicon (bSi) fabricated by reactive ion etch (RIE) and passivated by hydrogenated amorphous silicon (a-Si:H). We demonstrate minority effective lifetime over $1.5 \mathrm{~ms}$ for the best bSi surfaces, corresponding to over $700 \mathrm{mV}$ of implied open circuit voltage, values higher than on reference surfaces prepared by KOH etching. Fabrication of solar cells resulted in promising efficiency of $16.1 \%$ for $\mathrm{bSi}$ as compared to $18.5 \%$ for $\mathrm{KOH}$ references. Quantum efficiency measurements revealed that the bSi cells lose approximately $0.5 \mathrm{~mA} \mathrm{~cm}$-2 of current density in the visible and of $0.8-1 \mathrm{~mA} \mathrm{~cm}^{-2}$ in the infrared (IR) region. Current work is ongoing to further reduce surface damage during RIE to maximize the open circuit voltage and to optimize the deposition of a-Si:H on our bSi in order to reduce the loss in current density.
\end{abstract}

Index Terms - silicon heterojunction, a-Si:H, black silicon.

\section{INTRODUCTION}

Black silicon (hereinafter bSi) [1,2] has demonstrated great potential as texturing method $\mathrm{Si}$ photovoltaics thanks to its excellent intrinsic antireflective properties both at normal and at high incidence angles [3]. Power conversion efficiencies between 18 and $22 \%$ have been achieved in the lab using laserdoped selective emitters [4], $\mathrm{Al}_{2} \mathrm{O}_{3} / \mathrm{SiN}_{\mathrm{x}}$ passivation stacks, [5], and interdigitated back contact (IBC) cells [6]. These results have been obtained using maskless reactive ion etch (RIE) for the Si texturing. The increased surface recombination due to increased surface area and process-induced damage currently limits the open circuit voltage $\left(V_{\text {oc }}\right)$ and therefore the efficiency of RIE textured solar cells. Hydrogenated amorphous Si (a$\mathrm{Si}: \mathrm{H})$ is an outstanding passivation layer on $\mathrm{Si}[7]$ and is the core of the silicon heterojunction solar cell (SHJ) technology that holds the current record for single junction Si solar cell at 26.7\% [8]. a-Si:H seems therefore an appropriate candidate to passivate a notoriously challenging surface such as RIEtextured Si. Passivation of bSi fabricated via metal assisted chemical etch using a-Si:H was attempted by Mews et al. and showed promising results [9]. Here, we present our first attempt at combining RIE bSi with a-Si:H passivation. We demonstrate excellent lifetime results, with the best bSi wafer showing higher implied $V_{\text {oc }}\left(i V_{\text {oc }}\right)$ than a microstructured surface with pyramids obtained by conventional alkaline texturing. Preliminary results from solar cell fabrication showed lower conversion efficiency for the bSi-based cells as compared to the reference cells. Quantum efficiency measurements give indications on how to improve the efficiency of cells based on a-Si:H/bSi .

\section{METHODS}

4", $350 \mu \mathrm{m}$ thick CZ n-type (100) Si were used as substrates. RIE texturing was performed in a SPTS Pegasus system with: process temperature of $-20^{\circ} \mathrm{C}, \mathrm{SF}_{6}$ and $\mathrm{O}_{2}$ plasma with 7:10 gas flow ratio, $38 \mathrm{mT}$ Torr chamber pressure, $3000 \mathrm{~W}$ coil power, 10 $\mathrm{W}$ platen power. The process time was varied between 6 and 30 min. These wafers where then RCA cleaned, without the last $\mathrm{HF}$ dip to keep the chemically grown $\mathrm{SiO}_{2}$ layer on the surface. The pyramid texture, as for the reference, was prepared by $\mathrm{KOH}$ based alkali etching at $83{ }^{\circ} \mathrm{C}$ for $20 \mathrm{~min}$. The a-Si:H i/p an $\mathrm{i} / \mathrm{n}$ passivation layers were deposited by plasma enhanced chemical vapor deposition (PECVD) at temperature range of $140-160{ }^{\circ} \mathrm{C}$ with $\mathrm{SiH}_{4}, \mathrm{H}_{2}$ gas for intrinsic and also $\mathrm{B}_{2} \mathrm{H}_{6}$ and $\mathrm{PH}_{3}$ gas for $\mathrm{p}$ - and $\mathrm{n}$-doped layer. Scanning electron microscopy was performed in a SEM (Hitachi S-4300) at an accelerating voltage of $10 \mathrm{kV}$. Minority carrier lifetime was measured using the quasi-steady state photoconductance (QSSPC) method with a Sinton WCT120TS instrument. The lifetime shown in this study was obtained for the sample with both the front and rear surface passivated with only i a-Si:H layer. Prior to fabrication of solar cells, the Si substrates were cleaned according to [10]. The cell structure was the following: Ag-grid / ITO (75 nm) / p a-Si:H (5 nm) / i a-Si:H (10 nm) / n c-Si substrate $(350 \mu \mathrm{m}) / \mathrm{i}$ a-Si:H $(10 \mathrm{~nm}) / \mathrm{n}$ a-Si:H $(7 \mathrm{~nm}) /$ ITO / Ag. The cell designated area was $1.045 \mathrm{~cm}^{2}$, including the Ag grid. The performance $\left(V_{\mathrm{oc}}, J_{\mathrm{sc}}, F F\right)$ was characterized by the current-voltage $(J-V)$ measurements at a standard condition (AM1.5 1-Sun at $25{ }^{\circ} \mathrm{C}$ ). The external quantum efficiency spectra were measured under white light bias. 


\section{RESULTS}

Fig. 1 shows cross-section SEM images of bSi samples with different RIE time, as well as of the $\mathrm{KOH}$ textured reference. The surface of the bSi is characterized by hillock-like structure with height and base that generally increase with increasing RIE time. In particular, the height changes from approximately $200 \mathrm{~nm}$ for $6 \mathrm{~min}$ RIE to more than $1 \mu \mathrm{m}$ for $30 \mathrm{~min}$ RIE.
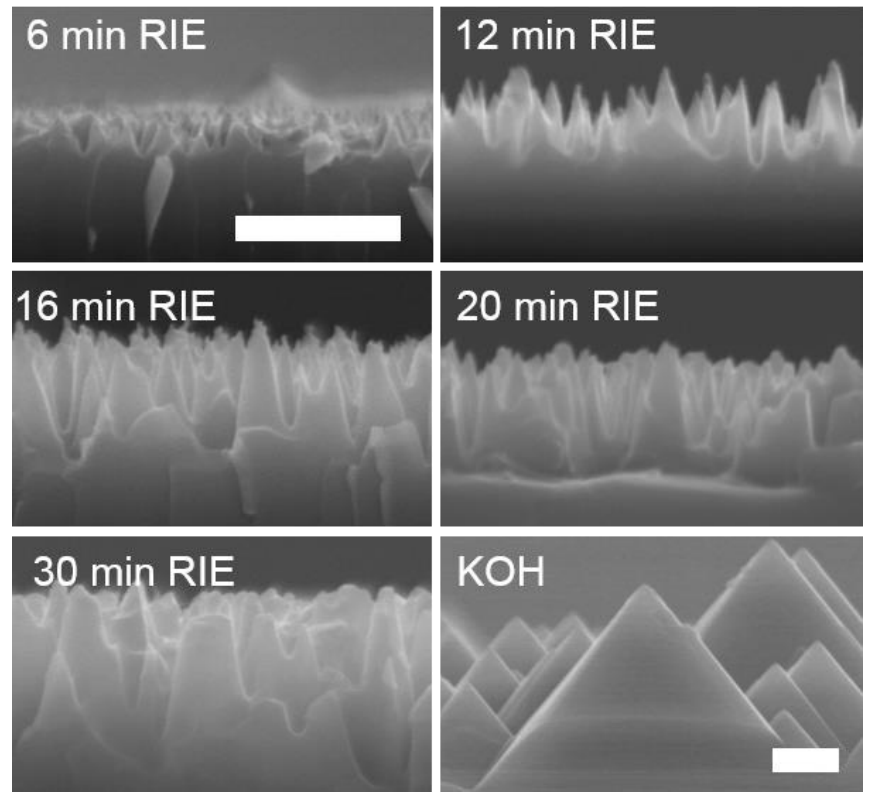

Fig. 1. Cross-section SEM images of Si surfaces textured by RIE and $\mathrm{KOH}$. Both scale bars represent $1 \mu \mathrm{m}$.

Measurements of minority carrier effective lifetime $\tau_{\text {eff }}$ as function of injection level $\Delta n$ reveal that the quality of passivation by a-Si:H is strongly affected by the RIE time, as shown in Fig. 2(a). For $6 \mathrm{~min}$ RIE, $\tau_{\text {eff }}$ is above the one measured on the $\mathrm{KOH}$ textured surface for injection higher than $5 \times 10^{14} \mathrm{~cm}^{-3}\left(\tau_{\text {eff }}=1.52 \mathrm{~ms}\right.$ for $6 \mathrm{~min}$ RIE and $\tau_{\mathrm{eff}}=1.27$ for $\mathrm{KOH}$ texturing.) $\tau_{\text {eff }}$ decreases considerably for $12 \mathrm{~min}$ RIE, remains approximately the same for $16 \mathrm{~min}$ RIE and then drops further for 20 and $30 \mathrm{~min}$ RIE. These values translate into $i V_{o c}$ values of 706 and $695 \mathrm{mV}$, respectively (see Fig. 3(c)). If fully exploited, this would lead to the highest $V_{o c}$ measured on bSi based solar cells. We speculate that the drastic decrease in $\tau_{\text {eff }}$ for RIE time of $12 \mathrm{~min}$ and longer may be due to less-completed surface coverage of the $\mathrm{i} / \mathrm{p}$ and $\mathrm{i} / \mathrm{n}$ a-Si:H passivation layer, which is currently under investigation.

Solar cells were fabricated from the 6 min RIE wafers as well as from the $\mathrm{KOH}$ textured wafers as reference. Results are summarized in Fig. 3. It is clear from the $J$ - $V$ curves (top panel) that the $\mathrm{KOH}$ textured cells average performance is higher than that of the bSi cells. The $\mathrm{KOH}$ textured cells display a higher $J_{\text {sc }}$ by $1.33 \mathrm{~mA} \mathrm{~cm}^{-2}$, a higher $V_{\text {oc }}$ by $16 \mathrm{mV}$, and a higher fill factor (FF) by $5.9 \%$, resulting in a $2.4 \%$ higher efficiency $(18.5$ against $16.1 \%$ ). We note that there is quite some room for improvement as the results presented here are from our first
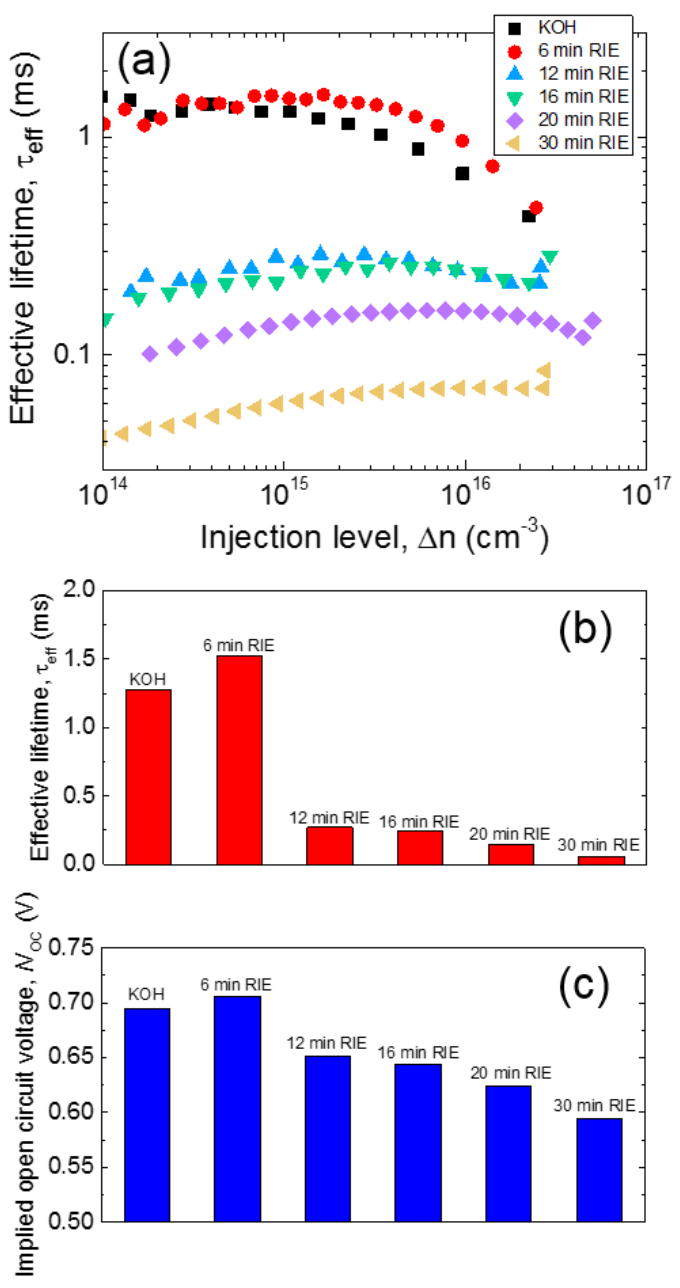

Fig. 2. Summary of lifetime measurements. (a) Effective lifetime as function of injection level. (b) Effective lifetime measured at injection level of $10^{15} \mathrm{~cm}^{-3}$. (c) Implied open circuit voltage calculated at injection level of $10^{15} \mathrm{~cm}^{-3}$.

batch of cells. The trend between $i V_{\mathrm{oc}}$ and $V_{\mathrm{oc}}$ is reversed: the net loss going from lifetime samples to full solar cells is of 27 $\mathrm{mV}$ when replacing $\mathrm{KOH}$ texturing with RIE. Possible reasons for this may include ITO sputtering damage to bSi and a higher shunt resistance caused by non-optimal contact between bSi and ITO. Poor contacting could also explain the rather large difference in $F F$ is rather large between these samples. There are two spectral regions where the $\mathrm{KOH}$ cells perform better than the RIE cells (see bottom panel of Fig.3), in the visible (400-700 nm) and close to the bandgap of Si (1000-1200 nm). By spectral weighted integration of the QE curves, we concluded that the loss in $J_{\mathrm{sc}}$ for the RIE cells is of $0.5 \mathrm{~mA} \mathrm{~cm}-$ 2 in the visible and of $0.8-1 \mathrm{~mA} \mathrm{~cm}^{-2}$ in the IR. Interestingly, Mews et al. reported a higher $J_{\mathrm{sc}}$ loss in the visible and a lower loss in the IR as compared to our results, which may be connected to difference in the characteristic shape and size of bSi. In our case, the loss in the IR is due to poor light trapping of the bSi caused by the relatively small characteristic size and by the shape of the nanostructures, as discussed in [11]. While 

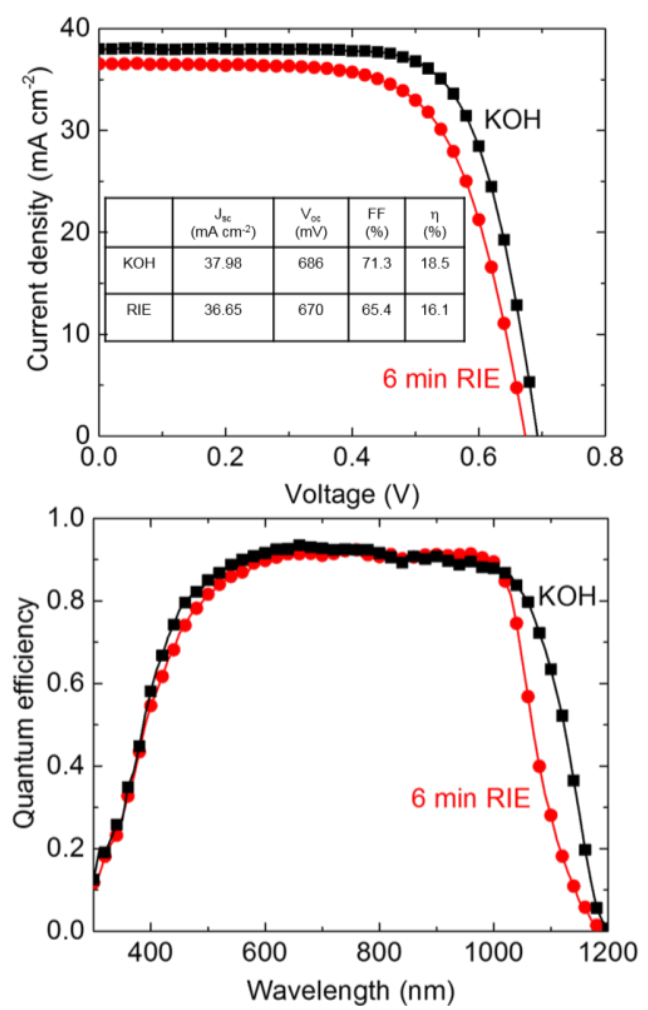

Fig. 3. Top: Averaged J-V curves for 6 min RIE textured cells and for $\mathrm{KOH}$ textured reference cells. Bottom: quantum efficiency measurements

texturing both sides of the cell might ameliorate this issue, further work on the RIE is needed to produce structures with more appropriate shape and even lower additional surface damage. It is difficult to determine the cause of loss in the visible from the data presented here, nonetheless we speculate that this could be due to enhances parasitic absorption in the a$\mathrm{Si}: \mathrm{H}$ as compared to the $\mathrm{KOH}$ textured cells. Since the $\mathrm{bSi}$ nanostructures are more convex than the pyramids, the effective thickness of incoming photons in the bSi textured surface could be higher.

\section{CONCLUSIONS}

We presented a combination of black silicon fabricated by RIE and a-Si:H films for surface passivation. We measured minority effective lifetime exceeding $1.5 \mathrm{~ms}$ for the best $\mathrm{bSi}$ surface, corresponding to over $700 \mathrm{mV}$ of implied open circuit voltage, a higher value than a reference $\mathrm{KOH}$ textured wafers. Fabrication of solar cells resulted in promising efficiency of $16.1 \%$ for bSi as compared to $18.5 \%$ for $\mathrm{KOH}$ references. Quantum efficiency measurements revealed that the bSi cells lose approximately $0.5 \mathrm{~mA} \mathrm{~cm}^{-2}$ of current density in the visible and of $0.8-1 \mathrm{~mA} \mathrm{~cm}^{-2}$ in the IR. Current work focuses on further reducing surface damage during RIE and on optimizing the deposition of a-Si:H on the bSi. In addition, the efficiency is likely to be increased by resorting to substrates with better bulk quality.

\section{ACKNOWLEDGEMENT}

The authors thank A. Sato for her expertise on solar cell fabrication and characterization. This work was supported by funding from EUDP (project number 64016-0030) and by JSPS KAKENHI Grant Number 15K04717.

\section{REFERENCES}

[1] H. Jansen, M. de Boer, R. Legtenberg, and M. Elwenspoek. "The black silicon method: a universal method for determining the parameter setting of a fluorine-based reactive ion etcher in deep silicon trench etching with profile control", Journal of Micromechanics and Microengineering, 5(2), 115, 1995.

[2] M. Otto, M. Algasinger, H. Branz, B. Gesemann, T. Gimpel, K. Füchsel, T. Käsebier, S. Kontermann, S. Koynov, X. Li, V. Naumann, J. Oh, A. N. Sprafke, J. Ziegler, M. Zilk, and R. B. Wehrspohn "Black Silicon Photovoltaics", Adv. Optical Matter. 3, 147-164, 2014.

[3] R.S. Davidsen, J. Ormstrup, M. L. Ommen, P. E. Larsen, M. S. Schmidt, A. Boisen, and O. Hansen, "Angle resolved characterization of nanostructured and conventionally textured silicon solar cells", Solar Energy Materials and Solar Cells, 140, 134-140, 2015.

[4] R. S. Davidsen, H. Li, A. To, X. Wang, A. Han, J. An, J. Colwell, C. Chan, A. Wenham, M. S. Stenbæk, A. Boisen, O. Hansen, S. Wenham, and A. Barnett, "Black silicon laser-doped selective emitter solar cell with $18.1 \%$ efficiency", Solar Energy Materials and Solar Cells, 144, 740-747, 2016.

[5] J. Benick, A. Richter, R. Müller, H. Hauser, F. Feldmann, P. Krenckel, and A. W. Bett, "High-efficiency n-type HP mc silicon solar cells", IEEE Journal of Photovoltaics, 7(5), 1171-1175, 2017.

[6] H. Savin, P. Repo, G Von Gastrow, P. Ortega, E. Calle, M. Garín, and R. Alcubilla, "Black silicon solar cells with interdigitated back-contacts achieve $22.1 \%$ efficiency", Nature nanotechnology, 10(7), 624-628, 2015.

[7] N. Jensen, R. M. Hausner, R. B. Bergmann, J. H. Werner and U. Rau, "Optimization and characterization of amorphous/crystalline silicon heterojunction solar cells", Progress in Photovoltaics, 10(1), 1-13, 2001.

[8] K. Yoshikawa, H. Kawasaki, W. Yoshida, T. Irie, K. Konishi, K. Nakano, T. Uto, D. Adachi, M. Kanematsu, H. Uzu and K. Yamamoto, "Silicon heterojunction solar cell with interdigitated back contacts for a photoconversion efficiency over 26\%", Nature Energy, 2, 17032, 2017.

[9] M. Mews, C. Leendertz, M. Algasinger, S. Koynov and Lars Korte, "Amorphous/crystalline silicon heterojunction solar cells with black silicon texture", Phys. Status Solidi RRL, 8(10), 831835, 2014.

[10] S.N. Granata, T. Bearda, F. Dross, I. Gordon, J. Poortmans and R. Mertens, "Effect of an in-situ $\mathrm{H}_{2}$ plasma pretreatment on the minority carrier lifetime of a-Si:H(i) passivated crystalline silicon”, Energy Procedia. 27, 412-418, 2012.

[11] M. Plakhotnyuk, M. Gaudig, R. S. Davidsen, L. M. Lindhard, J Hirsch, D. Lausch, and O. Hansen, "Low surface damage dry etched black silicon". Journal of Applied Physics, 122(14), 143101, 2017. 